\title{
Land Acquisition
} and Dispossession

\section{Private Coal Companies in Jharkhand}

KUNTALA LAHIRI-DUTT, RADHIKA KRISHNAN, NESAR AHMAD

This article presents an

investigation into strategies

employed by privately-owned

companies to gain access to land

for resource extraction in

Jharkhand where much of the

land being put under the shovel is inalienable adivasi or tribal land

and deedless commons. It

concludes that although policy

reforms are welcome, cosmetic

changes in mineral governance

laws are inadequate to protect the

interests of the poor. It suggests

an alternative vision, a complete

overhaul of mineral ownership to

allow the poor to share the

revenue benefits.
Kuntala Lahiri-Dutt (kuntala.lahiri-dutt@anu. edu.au) is fellow, Resource Management in Asia Pacific Programme, Crawford School of Economics and Government, Australian National University. Radhika Krishnan (krishnanradhi@gmail.com) is a doctoral candidate at Jawaharlal Nehru University, New Delhi and an independent researcher. Nesar Ahmad (ahmadnesar@gmail.com) is a research fellow, Budget Analysis Rajasthan Centre, Jaipur.

\section{Losing Land to Mining}

W hen Vishnu Ganju, a long-time resident of Hempur village of Balumath block in district Latehar $^{1}$ fell ill with tuberculosis, the representatives of a coal mining company took him to hospital for treatment. Vishnu was then asked to put his thumb impression on some papers, which he thought were related to his medical treatment. Later, it transpired that they were legal papers sealing the sale of his inherited land. Back in the village, the representatives opened a bank account for Vishnu to deposit the compensation money. While such blatant deception of illiterate or semi-literate, tribal/adivasi/indigenous ${ }^{2}$ or low-caste villagers to give away their land may be uncommon, it is not the only means by which land is being acquired in Jharkhand to accommodate the expansion of captive ${ }^{3}$ coal mining for power and steel production. Middlemen pressure peasant farmers to sell their land; Puran Ganju of Hempur village was coerced into selling off his land. Chedi Ganju, also from this village, claimed that he has neither received the receipt for the sale nor the full amount for the land he supposedly has sold.

India had legislated the Chhottanagpur Tenancy Act (CNTA) of 1908 to make such land inalienable. Why cannot this and other legislation such as the Panchayats Extension to Scheduled Areas (PESA) Act prevent acquisition of tribal land for coal mining and protect their livelihoods? What does such complicity of the state in allowing land transfers from poor peasants to mining-industrial corporations suggest about the nature of development being pursued by India? Lastly, how are Vishnu, Puran and Chedi's stories connected to the "big picture", the relationship between state, people, resources and capital? We sought the answer through investigating land transfers in North Karanpura collieries in Jharkhand. One of the authors (Radhika Krishnan) undertook an exploratory field survey in late 2009. She visited Gumla, Latehar and Hazaribagh districts. This fieldwork complemented ongoing research by two of the authors (KLD and NA) in Hazaribagh (Ashoka-Piparwar mines) area. To be objective, various "stakeholders" were interviewed; these included company officials and representatives of the Jharkhand Pollution Control Board (РСВ), a number of key resource persons, and villagers. Secondary data such as environmental impact assessment (EIA) reports, literature published by the companies and distributed amongst the villagers, and pamphlets released by nongovernmental organisations (NGOS) and activist groups were collected. ${ }^{4}$ Material from РСв and the Jharkhand government were also used. These were supplemented by a literature review.

The state argues that in today's globalised world, rapid expansion of capitalintensive mining and industry can enhance economic growth and improve rural people's livelihoods. If globalisation is "locally experienced", as suggested by Randeira (2003: 325), then asking these questions can unravel far more than what is detailed in the statements and memorandums of the Government of India. Tribal land acquisition for captive coal mining demonstrates the "violence" of mining and reveals the formal and informal tactics deployed by the state and private companies to dispossess the poor. This research, although conducted in 2009, is still relevant in that it illuminates the dark backyard of shining India. The gaps in the national policy process and the implementation of mining-related policy are also illuminated. The investigation also shows that a solution to "the problem of land acquisition" for infrastructural purposes, as suggested by some economists, cannot be left to the market because, at the micro level in rural India, the land market operates informally. ${ }^{5}$ Coal is specific within the 
overall "mining boom" because of the special status granted historically to it in postcolonial India. ${ }^{6}$ Coal was associated with nationalism and the working-class movement, and has assumed an iconic status as a national asset. The Coal India Limited (CIL) symbolised "public interest", and Acts such as the Coal Bearing Areas (Acquisition and Development) Act (CBAA) legislated to circumvent the protective legislation for tribals.

Jharkhand is not exceptional; other Indian states have also welcomed mining corporations to generate revenues. To assist mining-led growth, they have also acted as land brokers, adopted policies and changed mining legislation. Jharkhand is unique in its continued existence as a resource-periphery for India's centre and in its complicated "ethno-national frame" which was the raison d'être for its creation in 2000. Stuligross (2008: 83-84) considers that tribal people have never comprised a majority of the Jharkhand population, but Upadhyay (2009) affirms that the demand for a separate state of Jharkhand symbolised tribal aspirations of regaining control over land and resources. Attachment to land is one of the aspects of tribal identity, though it is arguable to what extent. The state has experienced intense struggles over land, minerals, forests, agriculture and water; resource ownership is contested and its control is linked with power (Jewitt 2008). Stuligross (2008: 87) is of the opinion that, even before the current mining boom, the government had become the major land alienator since the 1960 s. Consequently, two groups of people supported statehood: those who wanted to restrict land sale by the individual tribal, and those who sought to broaden the property market under the supervision of a Jharkhand state. The process of land acquisition for mining has neither been straightforward nor smooth, whether by CIL or privatelyowned companies.

\section{Taking Land for Raking Coal}

Throughout the world, interrelated crises in food, finance, energy and climate have been spurred by corporate-driven globalisation, neo-liberal policy regimes and natural resource exploitation. The global wave of land grabbing had serious consequences on the rural poor (as per the Land Research Action Network's 2011 report). Even the World Bank (2011) estimated that over 45 million hectares of land was bought from farmers in the developing world in 2009, a tenfold rise from the previous decade. ${ }^{8}$

Resource restructuring in post-liberalisation India involves securing land from farmers to allow for commercial and industrial uses, including mining. Coal dependence in overall energy supplies has led to acquisition of coal from overseas as well as the granting of mining blocks to private companies for "captive" coal mining. Indeed 44 captive coal blocks in Jharkhand have been allotted to private companies manufacturing sponge iron, integrated iron and steel, cement and power. 9 Between 2005 and 2009, 34 companies were allotted coal mining blocks in 210 villages in the Karanpura Valley alone. ${ }^{10}$ Some of the companies involved in captive coal mining in India have substantial foreign equity ${ }^{11}$ and generally they operate open-cut mines that have a significant ecological footprint and serious social consequences (Lahiri-Dutt 2007). As long as CIL was the sole operator in coal extraction, the company-community-government relationship could be dictated by the eminent domain principle. But when privatelyowned corporate entities enter the picture, it becomes problematic for the state to justify "public interest". A liberalised coal mining industry throws up a dilemma: does the state protect its poor and weak citizens or does it assist private capital and corporations?

To avoid the moral quandary, the state equates coal with national development, energy security and hence strategic sovereignty. Coal is presented as indispensable to meet India's huge energy need, which, once met, will light up electric bulbs in rural homes and raise literacy levels to assist in the growth of India's "soft-power". As for energy security, coal mining even becomes one of the keys to reinforce the sovereignty of India, and allowing private companies to mine coal at a large scale to quickly expand production becomes imperative. The framing of the problem itself invokes only one solution, that is to expand coal extraction, and the need arises to forcefully overcome any obstacles that might obstruct the expansion of coal mines.

A major hurdle is the acquisition of land for coal mining. When a privatelyowned company acquires mineral-rich land, the "eminent domain" principle which vests sovereign ownership of all land and natural resources embodied in the state and the notion of "public interest" - cannot (and should not) be invoked (see, for example, Singh 2010 and Chaudhary 2009). Yet, old legal instruments of colonial vintage such as the Land Acquisition Act (LAA) of 1894 continue to be used to procure land from peasants. In Jharkhand, coal lies under forest tracts owned (or customarily used) by the tribals, land that is legally inalienable. The concept of eminent domain allows both the LAA and CBAA to have precedence over any other acts (Guha 2006: 157). The CBAA was passed in 1957 to "establish greater public control over the coal mining industry and its development, provided for the acquisition by the state of unworked land containing coal deposits or of rights in or over such land". ${ }^{12}$ It, thus, fully reflects the older "commanding heights" philosophy. When manipulated by private corporations to get the revenue-hungry state governments to procure land for profit-making for shareholders, it can be a deadly weapon.

The state's complicity in using this instrument is evident in its pro-industrialisation policies, policies that often benefit the richer classes at the cost of the poor and the environment, but which are adopted in the name of improving the lot of the poor. ${ }^{13}$ More importantly, by virtue of the CBAA, the mining of coal generally supersedes the community rights (Sharma 2003). Procurement of land, particularly tribal land, without free and prior consent, can have devastating effects on small landholders. When the state acts as the facilitator of the land transfer process, its partiality towards large corporations is exposed (Levien 2011: 71). Such a "land broker" state is different from the old developmental state (Polanyi 2001 [1944]). The unholy alliance between state and "vulture capitalism" actually embodies a predatory growth (Walker 
2011) that enables corporate access to land but dispossesses the poor. David Harvey (2003) places the dialectical relationship between the politics of state and capital accumulation in space and time at the centre of the analytical framework of "capital bondage". Such neo-liberal developmentalism raises the question of social justice, and questions the very legitimacy of the state.

As is evident from the official Industrial Policy of Jharkhand $2001^{14}$ the state has adopted the role of facilitator in land acquisition processes to assist and encourage the rapid expansion of mining by private companies. The ability of corporate bodies to acquire and control land has been facilitated by a series of strategic amendments to the CNTA of 1908 and the Bihar Tenancy Act ${ }^{15}$ (Sharan 2009: 84-85). ${ }^{16}$ The government intends not to be a neutral arbitrator in the land acquisition process; the blueprint of industrial policy allows it to actively intervene on behalf of companies. It is contemplating to set up "land-banks" that would contain information on all land available for industrial development. In addition, it is establishing "private industrial estates" for prospective entrepreneurs.

In the context of coal mining, the participation of the state in the land acquisition process for private companies is less straightforward given that coal mining is theoretically nationalised. The CBAA states that the Act can be invoked only to acquire land for coal mining by government companies ${ }^{17}$ and similarly, the LAA of 1894 can be invoked only "to obtain land for the erection of dwelling houses for workmen employed by the Company or for the provision of amenities directly connected therewith". ${ }^{18}$ The LAA cannot be used by the state to acquire the entire amount of land required by private companies. The LAA is, thus, being invoked in three major ways. First, land is acquired under Part II of the Act 1984 instead of Part VII, paying part of the compensation from the government exchequer. ${ }^{19}$ Second, land is acquired by invoking the emergency clause (Section 17) (Singh 2010). Third, since there is no definition of public purpose given in the Act, the collector can define any industrial project as a public purpose (see the critique of land acquisition process in Choudhary 2009).

\section{State's Commitment to Industry}

The proposed Land Acquisition and Resettlement and Rehabilitation (LARR) Bill 2011, currently before the Parliament, has provision to acquire land fully or partially on behalf of the private companies, only if prior consent is given by $80 \%$ of the population affected by a project. However, it was found during fieldwork that the Jharkhand government informally committed itself to acquire $30 \%$ of the total land required by the companies. The companies, however, submit requisitions for more land than is actually needed. The government acquires gair majurwa or deedless land ${ }^{20}$ that has been used for generations by communities but is not recorded as such. Prem Prakash Soren, an activist with the local NGo Adivasi-Moolvasi Astitva Raksha Manch (AMARM), is working with the villagers in their protest against ArcelorMittal's proposed 12 million tonne "mega" steel plant. Soren claimed that villagers have observed the company representatives quoting contradictory figures for the land requirement. ${ }^{21}$ At the time of the survey, the government had identified a total of 1,025 acres to meet ArcelorMittal's land requirement. Much of this is common land; in Kamdera block (in Gumla district) alone, the commons around 10 villages have been handed over to the company. AMARM claims that this is a blatant contravention of community rights clearly mentioned in Khatiyan Part II of CNTA. Similar experiences were echoed in other parts of the state where the government is acquiring land for captive coal mining for private companies. ${ }^{22}$

\section{Informal Tactics}

Land acquisition by private companies in Jharkhand has also been characterised by the application of state force, and covert coercion by both company representatives and state agencies. During our focusgroup discussions in Harla and Gondalpara villages in Hazaribagh district and in Hempur village in Latehar, villagers said that notices of land acquisition are issued without detailed field surveys, and sometimes acquisition is done based on remotely sensed satellite data as both government and company representatives are wary of meeting angry villagers. Gram sabhas are often poorly informed regarding plans for land acquisition. ${ }^{23}$ Middlemen who broker the sales deal often cheat villagers. Activists are slapped with court cases to discourage them from organising resistance against forced evictions or forced sale of land. Deepak Das, a worker of the Karanpura Bachao Sangharsh Samiti (квss) and the Dalit Vikas Sangathan (DVs) noted that the police prevent activists from campaigning near land acquisition sites.

The example of land acquisition for Chitarpur Coal and Power (owned by the Abhijeet Group of Industries) in Balumath block of Latehar district is a case in point. At the time of this survey, the company had only acquired about 200 acres (due to opposition to the project) and on which the company has constructed its office - its mining operations had yet to begin. The prices paid for land can vary widely. Abhijeet Group raised the offer as the scale and intensity of protests grew. Again, the purchase process is far from transparent; the papers of those who have sold their land show that the buyer is one S K Jha, the assistant manager of Chitarpur Coal and Power. ${ }^{24}$ The court tends to refuse access when activists tried to use the Right to Information Act to retrieve sale documents.

\section{New Refugees Displaced by Coal}

Mining not only leads to changes in land-use pattern and the creation of "wastelands", ${ }^{25}$ it also leads to the physical and occupational displacement of people. Over a million people have been displaced due to coal mining alone between 1950 and 1995 (Bhusan and Hazra 2008: 164), but these figures are not comprehensive because there are no official record of mining-induced displacement. With more open cut mines, the situation can only get worse.

Displacement figures provided in EIA reports by the companies are not entirely reliable. Villagers claim that actual numbers are more than that declared by the companies. Being essentially focused on the environment, the EIA reports do not account for secondary/occupational displacement or displacement from 
mining-related activities. For instance, land requirement for the construction of a dam or waste disposal facilities is not mentioned. For example, the EIA of Chakra Opencast Mines project in Latehar, meant to supply coal to the 2,00o Mw Tori power station, notes that only 211 households will be displaced (Table 1). However, Kalender Ganju, gram pradhan of Hempur village claims that at least 12,00o people from five villages will be displaced by the project.

\begin{tabular}{l} 
Table 1: Displacement Caused by Land Acquisition (as Declared by Mining Companies) \\
\hline \begin{tabular}{lccc} 
Company & $\begin{array}{c}\text { Annual Capacity } \\
\text { of Coal (in million } \\
\text { tonnes/year) }\end{array}$ & $\begin{array}{c}\text { Land } \\
\text { Requirement } \\
\text { (in hectares) }\end{array}$ & $\begin{array}{c}\text { Estimated Displacement } \\
\text { in EIA (Number of } \\
\text { People/Families) }\end{array}$ \\
\hline Essar Power Jharkhand (Chakra Opencast) & 4.5 & 900 & 211 families \\
\hline Neelanchal Ispat Nigam & 1.3 & 383 & 1,737 \\
\hline Chitarpur Coal and Power (Abhijeet Group) & 0.68 & 1,378 & 149 \\
\hline Eastern Mineral Trading Agency & 3 & 491 & 1,158 \\
\hline Nico Jaiswal & 1 & 294 & Not available \\
\hline Source:Various ElA reports submitted by the companies to PCB and MoEF,Government of India, New Delhi.
\end{tabular}
\end{tabular}

The existing mechanism for estimating population displacement is insufficient in gauging the social impact of the proposed projects. Even if the companies claim that the quoted figures include only "legal" project-affected people, excluding the landless and those living on gair majurwa lands, the official assessments of impact should document their presence.

\section{Compensation, Rehabilitation and Resettlement}

As resistance to coal projects escalates, "adequate compensation" becomes politicised by companies upscaling their cash offers. ${ }^{26}$ Following a higher offer by the National Thermal Power Corporation, most private companies with mining block allotments in Badkagaon also began to offer sums of anywhere between Rs 1 lakh and Rs 5 lakh per acre. Such random decisions are dividing the village communities. In spite of better offers, many are unwilling to give up their lands as they realise that a one-off cash payment will not compensate for the permanent loss of livelihoods. Continued opposition is also rooted in the perception that payment is not commensurate with the financial revenues from marketing the coal. This brings home the issue of seeking a more socially-just means of benefit-sharing.

The Abhijeet Group of Industries had, in 2009, proposed to offer company shares to those willing to give up their land beginning by recognising malikana huk or local claims of ownership rights over mineral resources. The company has offered 500 shares per acre; however, these are at a fixed price and not at market value. ${ }^{27}$ The company is also offering community development projects which include technical training and allowance, but these are somewhat haphazard. It has also adopted the (old CIL) policy of offering employment to one member, depending on their competence, to each displaced family losing more than two acres of land besides a house or cash. Many villagers, however, remain sceptical that the company will actually meet these promises, and are still unwilling to settle for an uncertain future. Abhijeet, for instance, will only employ 350 people in the mines (as per EIA), of which only 55 jobs will be available to "semiskilled" and "unskilled" labour, the only types of work available to the local communities. No compensation is paid for the land used for the transportation of coal, and the air and noise pollution caused by truck movements. Villagers do not receive compensation for the water pollution caused by coal washeries or for the loss of natural water sources.

\section{EIAs: Toothless Safeguards}

Environmental impacts of mining do not necessarily remain within the boundaries of the leasehold area; watersheds and natural drainage systems, once tampered and local streams diverted, have far-reaching effects over wider areas. The pollution and depletion of water bodies also defy lease boundaries. The EIAS assess these impacts only within the leasehold areas. Almost all coal mining activity (opencast or underground) involves breaching the groundwater table. Though the water consumption of mines is not very high, the overall impact on local water regime is immense. Air pollution from mining activity, as well as the storage of overburden, is another major issue.

The EIAs do not document possible impacts on local water availability nor do they assess the ground-level impact of air pollution on surrounding communities and vegetation. The cumulative impacts of water and air pollution are rarely addressed in EIAS, which are generally insensitive to the multiple impacts on local communities. Generally, the EIAS present technical information that is devoid of the socio-economic and human context in which they exist, thus compromising their efficacy.

Consultation with the community and securing their prior and informed consent has been proposed globally (MMSD 2002) as the key to getting a "social licence to operate" by mining companies. The public hearing $(\mathrm{PH})$ component of EIAS is the Indian version of "Free, Prior and Informed Consent" (FPIC), but has no legal standing and the Ministry of Environment and Forests (MOEF) is not bound by its decision. Moreover, it unrealistically presumes equal power and a level-playing field between the company and the communities. A PH is seen as a one-off event rather than an ongoing interaction, and above all villagers do not have the right to refuse to sell land and stop a project. In addition, the company is not legally bound to address any issues brought up at the $\mathrm{PH}$ to the satisfaction of those present. The regulatory mechanism to implement EIAs and ensure the follow-up action is generally weak and "the regulating agencies in India within the oc [opencast] coal mines are not able to discharge their responsibilities of checking compliance effectively" (JhaThakur and Fischer 2008: 457). Consequently, the "regulating agencies act as policing agents, but the power in the regulation process is tilted towards developers" (ibid: 457). These limitations render the PH process impotent, yet the meetings are enthusiastically attended because it remains the only platform available for project-affected people to express their grievances. The resistance to projects naturally finds a voice at the PHs, to avoid which the companies often try to circumvent or manipulate the $\mathrm{PH}$ process in several ways: by changing the date of PH without notice (as in case of Nico Jaiswal) or by deferring it if a large crowd gathers (as in the case of EMTA's Badkagaon project) or by changing the 
location without notice (as in case of Abhijeet Group's PH in Latehar). State complicity is evident in that the РСв holds PHs without widely publicising it to avoid the leading activists to participate in them. Official communication from the Рсв requires the announcements to be placed in only two newspapers.

\section{Can Social Impact Assessments Deliver?}

The National Resettlement and Rehabilitation Policy (NRRP) of 2007, as well as the proposed LARR Bill of 2011, mandate that all projects must undergo a social impact assessment (SIA) before it is approved. ${ }^{28}$ Although it is better to have at least some social understanding rather than none at all, in absence of a strong, pro-human rights approach in mining legislation the SIA turns into a blunt tool. Currently, the SIA is a part of the EIA requirement, and is usually completed by environmental consultants, as an add-on section. As compared to other mining countries, where detailed ethnographic, cultural and social information on the village communities are gathered by SIA experts, the SIA sections of Indian EIAs do not offer much more than names of affected villages, the estimated number of displaced people, and some census data on the socio-economic characteristics of affected villages. Primary survey reports giving a meticulous picture of the possible economic, social, cultural and emotional impacts on communities are non-existent. The definition of "mineaffected villagers" is also limited; villages lying outside of the lease area are generally excluded even though they often suffer from the impacts of the mines (Lahiri-Dutt and Ahmad 2012). Mere numbers and figures, however, are not sufficient to assess the social impact of a project. To assess the attachment of villagers to land, and the role of land in supporting local livelihoods, it is necessary to document land productivity and the manner in which people depend on it, not just the amount of land. If forest land is being diverted, it is not enough to catalogue the varieties of trees and animals present in the forest (as is done in EIAS). To fully understand the impact of land-use diversion, the role of the forest (through firewood and minor forest produce) in supporting local livelihoods needs to be assessed. For this, a thorough assessment of the loss of livelihood from mining should be mandatory.

\section{Ethnicity Matters}

Activists offer two key arguments for why many tribals desperately oppose land acquisition: the first set of reasons is rooted in culture, the close relationship with land, and the tribal identity and existence being so entwined with land and with a long history, not just of suffering and exploitation, but also of resistance. The second set of reasons is rooted in the dependence on land-based resources for daily subsistence. One villager in Harl (Hazaribagh) observed: "We have neither education, nor political clout. All we have is this land. If we give up our land today, then can we hope that our children would become babus in these companies tomorrow?"

The close relationship with the land is not shared by absentee landlords living in the cities or shopkeepers and businessmen, who readily give up their land for cash. Father Tony Herbert, a missionary teacher in Hazaribagh for decades, points out that when large landowners sell land, the bataidars or sharecroppers, who are inevitably dalits, Other Backward Classes (овсs) or tribals lose out. Social conflicts over land acquisition by Neelanchal Ispat support this statement; while the dalits and adivasis are opposing the project, upper-caste Hindus and Muslims are favouring it. The struggle to protect tribal customs and the resistance against land acquisition are linked with and feed into, each other. The desire to preserve tribal culture partly arises from the perception that it is by circumventing traditional tribal customs and practices that celebrate community ownership and control of land, the state alienates tribals from their land. This is one of the reasons why the tribals are hanging tenaciously on to CNTA and PESA.

\section{Need for a New Paradigm}

In the early days of mineral-based industrialisation in Jharkhand, local communities were not entirely excluded and at least, as mine labourers, some "earned incomes in excess of anything they could have earned in their villages" (Corbridge 2004: 185). Today, they are not much better than "captives" on their own land as jobs in machine-driven open-cut mines are few. Coal mining by private companies points to a complex political power game played in the name of energy security. In this game, the more powerful, enjoying air-conditioned comfort of first-world lifestyles, invoke the poor for whose "development" the energy is needed. After proclaiming India's arrival on the world-stage, the powerful then allow the peripheries as resource-enclaves. The poor are forced to give up their livelihoods and become indebted bonded labourers; they may become illegal miners, or move to cities as beggars and crowd the urban slums. The rich and powerful then sit in climate change talks and invoke global justice to allow India to continue polluting the global commons.

Only a convoluted logic can equate coal mining by private companies with public purpose or "national interest". If globalisation and liberalisation aim to integrate India with the global economy then our industries should follow the sustainability principles proposed by the International Council of Mining and Metals or should keep up to date with contemporary global enterprises such as the Extractive Industries Transparency Initiative (EITI). Even then, doubts remain if these global solution templates would be useful for land acquisition as private coal mining in Jharkhand not only involves the violation of constitutional and legal provisions, it also illuminates the inadequacies of the regulatory framework to safeguard the poor. A cosmetic reform of mining-related laws, such as the ones under consideration, although an important task, is not the panacea. Land grabs for captive coal mining occur within a paradigm in which the contravention and manipulation of the law and the regulatory framework may be allowed with formal or tacit support of the state machinery. When companies face resistance and opposition in the process of acquiring land, they resort to informal strategies and methods which the regulatory framework is unable or unwilling to detect and control.

The critical issue is that the existing regulatory framework takes no account of and makes no provisions to mitigate the social impacts before and after the mining licence is granted. Greater awareness of the need 
to protect environmental integrity has ushered in the requirement of environmental clearance although compliance to regulations remains arguable. ${ }^{29}$ With regard to the society, however, the laws imagine a citizenry that is equal in every respect, all citizens playing on a level field but material and cultural impacts are not part of the sustainability agenda. They are seen as amorphous and claims by social researchers are deemed as unsophisticated, unscientific and unfounded statements. In the circumstances, one's identity is poised between that of an anti-mining activist and a pro-mining sycophant. Such generalisations lead to the production of a set of simplistic policy instruments such as the gamut of short-, medium- and long-term recommendations offered by one of the World Bank visiting teams in 2007.

It is not enough to reform the laws such as those currently under way ${ }^{30}$ in the absence of the state's capacity to act as an arbiter in relation to the rights and interests at stake. Decision-making with regard to the acquisition of land needs to be the result of negotiation. Such a "negotiated justice" regime might greatly improve mining governance compared to current products of adjudication or administrative decision-making, or purely private individual decision-making. These negotiations to secure social justice enshrine a liberal idea of self-determination that is embodied in FPIC/PH (Szablowski 2010: 112-13). Communities have not enjoyed personal autonomy to the extent that might make FPIC a useful instrument. Mining companies know that the poor cannot have the same bargaining power, and dissuade civil society organisations from participation in PHS. Those investing their capital and the communities that are mine-affected are on unequal bargaining positions, working with biased state machinery. Although their introduction is needed, one must remember that neither the addition of SIA, nor continuous engagement processes can fully address the gross imbalance of power.

We propose an overhaul of mineral governance in India. The state claims that sovereign ownership of all mineral resources is a result of the colonial past. It was during the colonial times that the dispossession of the poor located in resource peripheries began. In the neo-liberal present, this dispossession has been exacerbated and assumed more blatant forms with state assistance. Therefore, modifications or "legal reforms" of mining are not enough; to reshape the economic development of India's mineral belts, there is an urgent need to think about radical and fundamental changes in ownership.

\section{Moratorium?}

These gross injustices by corporatised enterprises exemplified in this article have led to some activists calling for a moratorium on mining. It is impractical to want to stop one of the most ancient human endeavours which formed the backbone of human civilisation. We need to develop a new mineral extractive paradigm, one that does not inflict deep wounds on nature and people, and one that is neither state nor corporate-dependent. Towards this, we propose an overhaul of mineral resource governance before further mining leases are granted. For this, possible alternatives to the ownership by the state of all minerals and the use of these resources by corporate entities need to be explored. This is not impossible; India has examples of community-led management in other areas of natural resources. People's right to land and its resources is being recognised, enshrined in laws and applied through participatory management.

To ensure poor communities full benefits from the resources of their land so that their livelihoods are transformed for the better, royalties should be paid to a tribal or local council on the amount of resources extracted. Those directly affected by mining would receive a proportion of the royalties, while the remainder would go to benefit a lot of people who used the land and its resources, sharecroppers or those who lived in the surrounding area.

The proposed Draft Mines and Minerals (Development and Regulation) Bill 2011 provides for sharing $26 \%$ of the profit of coal and lignite mining and amounts equal to the royalty in case of other major minerals mined. ${ }^{31}$ Instead of an easy one-stop shop, ${ }^{32}$ developing this elaborate framework would require an extended time for agreement-making and consent-seeking processes. No mining project should go ahead without the consent of tribals and poor landowners; they should have the right to refuse a project. Unless they have this key right, no situation could be truly "win-win". The proposed LARR Bill 2011 makes it mandatory to take the consent of the affected population only in this case of land being acquired for private companies and for public-private partnership projects. When the government acquires land for its own projects or private companies are buying land from farmers for their projects, the need for taking consent has not been deemed necessary. Currently, it is necessary to "consult" the gram sabha before initiating a development project in the Fifth Scheduled Areas, under the PESA Act. We think it should be amended to make it mandatory to take the "consent" of the gram sabha. This requirement should not be restricted only to the Fifth Scheduled Areas but be extended for the entire country.

A micro-level understanding of the flow of money into and changing power relations within the community and families would be essential to optimise the level of royalties and consequent benefits and/or continuing impacts on the communities. Civil society organisations could manage the scheme with regular inspections from the central government and in consultation with the states.

\section{NOTES}

1 Land in Hempur village is being acquired for a power plant, not for mining. Though our survey was about coal mining, Vishnu Ganju's experience illustrates the coercive practices used to acquire land.

2 Subsequently, the terms "tribals", "adivasi" and indigenous communities will be used interchangeably.

3 "Captive" implies mining of coal meant for an associated power station or steel-making, instead of the coal being sold in the market. In 1996, the MOC issued a notification allowing mining of coal for captive use for the production of cement.

4 Reports and other documents consulted: EIA reports submitted by Essar Power Jharkhand (nd), Neelanchal Ispat Nigam (nd), Chitarpur Coal and Power (nd), Eastern Mineral Trading Agency (nd) and Nico Jaiswal (nd); pamphlet, Karanpura Bachao Sangharsh Samiti (nd); brochure, Abhijeet Group (nd), news articles from Prabhat Khabar, Hindi newspaper published from Ranchi (various dates).

5 Morris and Pandey (2009: 27) point out to the need for a complete overhaul of the statutes, organisational structures and processes to develop a titling system that can ensure the security of tenure to land and property.

6 Coal is one of the "major" minerals as per the Mines and Minerals Development and Regulation Act (MMDR, originally passed in 1957, amended in 1988 and 2003), allowing only large-scale operators to carry out its mining. A new amendment to MMDR has been proposed that aims to offer $26 \%$ of profits to local communities.

7 Conventional texts describe Jharkhand as a 
"museum of mineral resources" and indeed it has been the major producer of a large number of minerals. Jharkhand accounts for $29 \%$ of India's coal reserves and contains the largest number of collieries in the country, accounting for $21 \%$ of Indian coal production in 2004-05 (Bhushan and Hazra 2008: 159).

8 Deininger et al (2011). See http://siteresources. worldbank.org/INTARD/Resources/ESW Sept7 final_final.pdf, viewed on 2o December 2011 .

9 "Details of Coal Blocks which Stand Allotted", see the website of MOC, available online at http://www.coal.nic.in/caplisto70709a.pdf (viewed on 18 January 2010).

10 According to information provided in a pamphlet issued by the Karanpura Bachao Sangharsh Samiti, available online at http://www. firstpeoplesfirst.in/jmacc-alliance.php (viewed on 11 November 2010).

11 Privately-owned Indian companies setting up or operating power projects as well as coal or lignite mines for captive consumption are allowed FDI of up to $100 \%$. One hundred per cent FDI is also allowed for setting up coal processing plants subject to some conditions (Singh and Kalirajan 2003: 145).

12 P 1. Full Act downloadable from http://coal. nic.in/cba-act.pdf, viewed on 8 December 2011.

13 Such as energy security of the country. Indeed about $40 \%$ of India's population do not have access to electricity as defined.

14 Available on http://jharkhandindustry.gov.in/ industry:policy.html.

15 This Act applies to Jharkhand as well. The industrial policy of Jharkhand refers to the amendment in the Bihar Tenancy Act.

16 CNTA was passed in 1908 to protect and recognise tribal rights over land. In 1996, mining and industrial purposes were included in Section 49 of the CNTA as reasons for which land could be transferred.

17 Page 4 of the Coal Bearing Areas (Acquisition and Development) Act, 1957, available from http:// coal.nic.in/cba-act.pdf viewed on 8 December 2011.

18 Part VII, Section 41, p 12 of the Land Acquisition Act, 1894. Available from http://dolr.nic.in/hyperlink/acq.htm, viewed on 9 December 2011.

19 Under the LAA the land can be acquired under either Part II or Part VII. Part II is used when land is acquired by the government or the public sector undertakings. Compensation is paid from government fund. Part VII makes provisions for acquisition for the companies for which a memorandum of understanding is signed between the company and the state government and compensation is paid by the company.

20 Gair majurwa land is a relic from the colonial land revenue surveys of the Chhotanagpur region. Literally it is "land without deed", i e, land that does not have legal papers to prove individual's ownership on it. Such lands generally include pastures, wasteland, roads and ponds, which have often been used or cultivated for generations and are hence owned de facto, or are well-utilised community lands.

21 According to Soren and Royan Kerkatta of AMARM, the company has sometimes quoted much higher figures - up to 12,000 hectares of land.

22 For instance, in the case of Nico Jaiswal's Moitra Coal Mining Project in Badkagaon block in Hazaribagh, the government has invoked Section 17 of the LAA in order to acquire land. Section 17 of the LAA (sometimes known as the Emergency Clause) vests "Special Powers" to the state in case of "urgency". According to it, if the collector so directs, the state can take possession of any land needed for "public purpose". Once acquired, such land is completely in the control of the government, "free from all encumbrances".

23 Gram sabha is literally a "village gathering" of which all legal adults are members and can take part in collective decisions pertaining to the village. The PESA Act recognises gram sabhas as the crucial decision-making unit under panchayati raj system and gives them important powers for consultation in the matter of land acquisition and development projects in the area. But, the Jharkhand Panchayati Raj Act has diluted PESA in this regard.

24 We were unable to procure documented proof of informal practices elsewhere, wherein land is sold not to the company but to an individual representing the company.

25 Grazing grounds and pastures routinely appear as "wastelands" in official records. In reality, the so-called wastelands are common property resources (CPRs), serving as the livelihood-base for millions of poor and marginalised.

26 To begin with, as the residents of the villages in the to-be-affected area report, the NTPC offered Rs 1.25 lakh per acre. Over the years, this has increased to Rs 10 lakh per acre - the most generous offer till date in the area.

27 According to a brochure issued by the company, each share can be sold three years later at the rate of Rs 200 per share.

28 The National Rehabilitation and Resettlement Policy itself has lost authority amongst the NGOs; a pamphlet issued by KBSS claims that the policy is practically an "investment and destruction" (nivesh and vinash) policy. The policy has also been criticised by others for its failure of fully addressing the concerns of the displaced and affected populations. See, for instance, a critique of the policy by the Asian Centre for Human Rights (2007).

29 See the recent study released by the Centre for Science and Environment that shows how easily environmental clearances are given in India to divert forestland to non-forest uses http://www.cseindia.org/userfiles/Overview. pdf (viewed on 20 December 2011).

30 See http://www.prsindia.org/uploads/media/ minesamendment.pdf for the new Mining Bill and http://rural.nic.in/sites/downloads/general/ LS\%20Version\%20of\%2oLARR $\% 20 \% 20$ Bill.pdf for the amendments in LAA and R\&R Bill.

31 Draft MMDR is available at http://pib.nic.in/archieve/others/2011/sep/d2011093002.pdf, (viewed on 20 December 2011). See sections 43 and 56.

32 This is one of the favourite jargons of economists at the World Bank to allow easy flow of capital investment.

\section{REFERENCES}

Asian Centre for Human Rights (2007): “India's Failed National Rehabilitation and Resettlement Policy, 2007", available on http://www. achrweb.org/Review/2007/198-07/html.

Bhushan, Chandra and Monali Zeya Hazra (2008): "Mining in the Sates: Jharkhand and West Bengal' in Rich Lands, Poor People: Is 'Sustainable' Mining Possible? State of India's Environment: Sixth Citizens' Report (New Delhi: Centre for Science and Environment).

Choudhary, Tarun (2009): "Use of Eminent Domain: Process and Its Critique" in India Infrastructure Report 2009: Land - A Critical Resource for Infrastructure, 3iNetwork, OUP, pp 75-76, also available online on http://www. iitk.ac.in/3inetwork/html/reports/IIR20o9/ IIR_2009_Final_July\% 2009.pdf.

Corbridge, Stuart (2004): "Competing Inequalities: The Scheduled Tribes and the Reservation System in India's Jharkhand" in S Corbridge, $S$ Jewitt and S Kumar (ed.), Jharkhand: Environment, Development and Ethnicity (New Delhi: Oxford University Press), pp 175-202. Originally published in Journal of Asian Studies, 59(1).

Deininger, Klaus and Derek Byerlee with Jonathan Lindsay, Andrew Norton, Harris Selod and Mercedes Stickler (2011): Rising Global Interests in Farmland: Can It Yield Sustainable and Equitable Benefits, Washington DC, World Bank.
Guha, A (2006): "Dispossession of Peasants by Industrial Projects" in S Jain and M Bala (ed.), The Economics and Politics of Resettlement in India (Delhi: Pearson Longman), pp 155-73.

Harvey, David (2003): The New Imperialism (Oxford: Oxford University Press).

Jewitt, Sarah (2008): "Political Ecology of Jharkhand Conflicts", Asia Pacific Viewpoint, 49(1): 68-82.

Jha-Thakur, Urmila and Thomas Fischer (2008): "Are Open-cast Coal Mines Casting a Shadow on the Indian Environment", International Development Planning Review, 30(4), Vol 30(4): 441-59.

Lahiri-Dutt, Kuntala (2007): "Illegal Coal Mining in Eastern India: Rethinking Legitimacy and Limits of Justice", Economic \& Political Weekly, XLII (49), 8 December.

Lahiri-Dutt, Kuntala and Nesar Ahmad (2012): "Considering Gender in Social Impact Assessments" in Frank Vanclay and Ana Maria Esteves (ed.), New Directions in Social Impact Assessments: Conceptual and Methodological Advances (Cheltenham: Edward Elgar).

Levien, M (2011): "Rationalising Dispossession", Economic \& Political Weekly, Vol XLVI, No 11, 11 March.

MMSD (2002): "Breaking New Ground: The Report of Mining Mineral and Sustainable Development Project", available on http://pubs.lied. org/pdfs/8084IIED.pdf? last viewed on 20 January 2011.

Morris, Sebastian and Ajay Pandey (2009): "Land Markets in India: Distortions and Issues" in India Infrastructure Report, 2009: Land - A Critical Resource for Infrastructure, IDFC (New Delhi: Oxford University Press).

Polanyi, Karl (2001 [1944]): The Great Transformation: The Political Economic Origins of Our Time (Boston: Beacon Press).

Randeira, Shalini (2003): "Glocalisation of Law: Environmental Justice, World Bank, NGOs and the Cunning State in India", Current Sociology, 51(3-4).

Sharan, Ramesh (2009): "Alienation and Restoration of Tribal Land in Jharkhand" in Nandini Sundar (ed.), Legal Grounds: Natural Resources, Identity, and the Law in Jharkhand (New Delhi: Oxford University Press).

Sharma, M (2003): Implications of the CBA Act and Coal India R \& R Policy on DPs and PAPs of Rajmahal Opencast Coal Mine Expansion Project, with focus on Necessity for Gender-Sensitive Rahabilitation Programme Development, Report Submitted as a project, Indira Gandhi National Open University, New Delhi.

Singh, Kanhaiya and Kaliappa Kalirajan (2003): "A Decade of Economic Reforms in India: The Mining Sector", Resources Policy, 29: 139-51.

Singh, Ram (2010): "Ending Misuse of Land Acquisition Act" in the Economic Times, 18 Novmber, available on http://economictimes.indiatimes. com/opinion/comments--analysis/Endingmisuse-of-land-acquisition-laws/articleshow/ 6944908.cms, viewed on 8 December 2010.

Stuligross, David (2008): "Resources, Representation, and Authority in Jharkhand, India", Asia Pacific Viewpoint, 49(1): 83-97.

Szablowski, David (2010): "Operationalising Free, Prior, and Informed Consent in the Extractive Industry Sector? Examining the Challenges of a Negotiated Model of Justice", Canadian Journal of Development Studies, 30(1-2): 111-30.

Upadhyay, Carol (2009): "Law, Custom and Adivasi Identity: Politics of Land Rights in Chhotanagpur" in Nandini Sundar (ed.), Legal Grounds: Natural Resources, Identity, and the Law in Jharkhand (New Delhi: Oxford University Press), pp 30-55.

Walker, Kathy le Mons (2011): "Neoliberalism on the Ground in Rural India: Predatory Growth, Agrarian Crisis, Internal Colonisation, and the Intensification of Class Struggle", Journal of Peasant Studies, 35(4): 557-620.

World Bank (2007): Jharkhand: Addressing the Challenges of Inclusive Development, Washington DC, World Bank. 